Mateusz Tarnowski', Anna Duda-Sobczak², Dorota Zozulińska-Ziółkiewicz², Marzena Wyganowska-Swiątkowska'

\title{
Insulinoterapia przy użyciu osobistej pompy insulinowej oraz lepsze wyrównanie glikemii związane z mniejszą akumulacją płytki nazębnej u dorosłych chorych na cukrzycę typu 1
}

\author{
Insulin therapy with the use of personal insulin pump and better glycemic control \\ are associated with lower accumulation of dental plaque in adults with type 1 diabetes
}

\author{
${ }^{1}$ Katedra i Klinika Chirurgii Stomatologicznej i Periodontologii, \\ Uniwersytet Medyczny im. Karola Marcinkowskiego w Poznaniu \\ ${ }^{2}$ Katedra i Klinika Chorób Wewnętrznych i Diabetologii, \\ Uniwersytet Medyczny im. Karola Marcinkowskiego w Poznaniu
}

DOI: http://dx.doi.org/10.20883/df.2018.18

\section{STRESZCZENIE}

Wstęp. Hemoglobina glikowana A1c (HbA1c) jest uznanym, standardowym wskaźnikiem oceny wyrównania metabolicznego cukrzycy i odzwierciedla ryzyko powikłań neurowaskularnych. Do typowych powikłań cukrzycy w jamie ustnej zalicza się przewlekłe i zaostrzone stany zapalne dziąseł i przyzębia, które same również zwiększają insulinooporność i zaburzają wyrównanie metaboliczne. Badania dowodzą, że istnieje wyraźny związek między stopniem wyrównania metabolicznego, wyrażonego oceną HbA1c a zdrowiem jamy ustnej u pacjentów z cukrzycą typu 1, przy czym im gorsze wyrównanie metaboliczne tym nasilenie objawów gingivitis większe, nawet przy dobrej higienie. W cukrzycy typu 1 rekomendowaną metodą leczenia jest intensywna funkcjonalna insulinoterapia (IFIT), w której dawka insuliny jest precyzyjnie szacowana względem aktualnego zapotrzebowania na insulinę. IFIT realizowana jest w formie wielokrotnych wstrzyknięć insuliny lub za pomocą osobistej pompy insulinowej.

Cel. Porównanie akumulacji płytki nazębnej u dorosłych osób z cukrzycą typu 1 leczonych metodą wielokrotnych wstrzyknięć insuliny lub ciągłego podskórnego wlewu insuliny za pomocą osobistej pompy insulinowej.

Materiał i metody. Do badania włączono 402 osoby (171 mężczyzn) z cukrzycą typu 1, w wieku 18-45 lat, z medianą trwania cukrzycy 12,5 roku. Dokonano pomiarów antropometrycznych, oznaczenia HbA1c, CRP, T-Chol. Przeprowadzono badanie stomatologiczne z oceną API. Grupę pacjentów podzielono w zależności od sposobu leczenia na MDI (wielokrotne wstrzyknięcia insuliny) oraz OPI (z osobistą pompą insulinową).

Wyniki. Grupę OPI stanowiło 47\% osób badanych. Charakteryzowali się: młodszym wiekiem, niższym BMI, niższym odsetkiem HbA1c, niższym stężeniem T-Chol i niższymi wartościami hs-CRP niż pacjenci z grupy MDI. Między grupami nie zaobserwowano różnic w zakresie płci i czasu trwania choroby; przy czym większość palaczy należała do grupy MDI. Wykazano dodatnią korelację API z wiekiem, HbA1c, T-Chol, hs-CRP, BMI. Leczenie OPI i płeć żeńska korelowała ujemnie API. W analizie regresji wieloczynnikowej niższa HbA1c i leczenie OPI były związane z niższym API niezależnie od wieku, płci, palenia papierosów i pozostałych czynników.

Słowa kluczowe: cukrzyca typu 1, zapalenie dziąseł, płytka nazębna, wielokrotne wstrzyknięcia insuliny, ciągły podskórny wlew insuliny, osobista pompa insulinowa.

\section{ABSTRACT}

Introduction. Hemoglobin A1c is a standard marker of metabolic control of diabetes and is associated with the risk of chronic neurovascular complications of diabetes. There are oral cavity diabetic complications like chronic and acute gingivitis and periodontitis. It is known that they may increase insulin-resistance and alter the metabolic control of diabetes. In the previous studies the relationship between metabolic control of diabetes assessed by $\mathrm{HbA1c}$ measurement and oral cavity health in patients with diabetes type 1 has been shown. The worse metabolic control, the higher intensity of bleeding in dental examination and so - more intense inflammation even in well maintained oral cavity. Intensive functional insulin therapy (IFIT) is currently recommended as the mode of treatment in type 1 diabetes. Insulin may be thus delivered by multiple daily injections (MDI) or continuous subcutaneous insulin infusion with personal insulin pump.

Aim. The aim of the study was to compare the dental plaque accumulation in adults with type 1 diabetes treated with multiple daily insulin injections or continuous subcutaneous insulin infusion with personal insulin pump. 
Material and methods. 402 (171 men) patients with type 1 diabetes, aged 18-45, with median diabetes duration of 12,5 years were examined. HbA1c, CRP, T-Chol were measured and dental examination with API assessment was performed. Patients were divided into subgroups according to the mode of insulin therapy.

Results. 47\% were treated with insulin pump. They were characterized by younger age, lower BMI, lower HbA1c, lower T-Chol and CRP with comparison to MDI patients. There were no differences in gender or disease duration, although more smokers were in MDI group. Positive correlation between API and age, $\mathrm{HbA1c}$, T-Chol, hs-CRP and $\mathrm{BMI}$ was observed. API correlated negatively with insulin pump treatment and female sex. In multivariate regression analysis lower $\mathrm{HbA1c}$ and insulin pump treatment were associated with lower API independently from age, sex, smoking and other factors.

Keywords: type 1 diabetes, gingivitis, dental plaque, multiple daily injections, continuous subcutaneous insulin infusion, personal insulin pump.

\section{Wstęp}

Hemoglobina glikowana A1c (HbA1c) jest standardowym wskaźnikiem ocenianym przy kontroli wyrównania cukrzycy, odzwierciedla średnią glikemię w poprzedzającym okresie około trzech miesięcy [1], przy czym około 50\% obecnej we krwi HbA1c powstaje w ciągu ostatniego miesiąca przed wykonaniem oznaczenia. Wykazano silną wartość predykcyjną HbA1c dla przewlekłych powikłań cukrzycy $[2,3]$. Cele leczenia cukrzycy obejmują uzyskanie wartości docelowych w zakresie: glikemii, ciśnienia tętniczego, lipidogramu, masy ciała [4].

Cukrzyca typu 1 rozwija się w przebiegu uwarunkowanego autoimmunologicznie procesu destrukcji komórek $\beta$ wysp trzustki prowadzącego do bezwzględnego niedoboru insuliny, dlatego też jedynym możliwym sposobem leczenia pozostaje insulinoterapia. Celem leczenia cukrzycy typu 1 jest dobra kontrola metaboliczna z utrzymywaniem w granicach możliwie bliskich normie stężenia glukozy we krwi, wartości HbA1c $\leq 6,5 \%$, o ile nie wiąże się to ze zwiększeniem ryzyka niedocukrzeń czy pogorszeniem jakości życia pacjenta. Tylko taki sposób postępowania już od początku zachorowania może zapobiec występowaniu ostrych i przewlekłych powikłań oraz umożliwić prowadzenie normalnego, aktywnego życia rodzinnego, zawodowego i społecznego [4]. Obecnie intensywna funkcjonalna insulinoterapia (IFIT) jest rekomendowaną metodą leczenia cukrzycy typu 1. Pozwala ona precyzyjne dostosować dawkę insuliny do aktualnego zapotrzebowania, uwzględnia zawartość węglowodanów w porcji posiłku, aktualną glikemię oznaczoną za pomocą glukometru lub systemu ciągłego monitorowania glikemii za pomocą specjalnego sensora umieszczonego $w$ tkance podskórnej oraz planowaną aktywność fizyczną. IFIT może być realizowana za pomocą wielokrotnych wstrzyknięć insuliny lub ciągłego podskórnego wlewu insuliny z użyciem osobistej pompy insulinowej (OPI). Badanie obserwacyjne grupy ponad
30000 dzieci i młodych dorosłych z cukrzycą typu 1 wykazało mniejszą częstość ostrych powikłań cukrzycy, tj. ciężkiej hipoglikemii i cukrzycowej kwasicy ketonowej oraz lepsze wyrównanie metaboliczne cukrzycy (niższy odsetek HbA1c) w grupie leczonej OPI w porównaniu z grupą leczoną metodą wielokrotnych wstrzyknięć insuliny [5].

Do powikłań cukrzycy typu 1 obserwowanych w jamie ustnej zaliczyć można: kserostomię, ropnie, zarówno przyzębne jak i okołowierzchołkowe, zmiany w obrębie śluzówki, zespół pieczenia $w$ jamie ustnej (burning mouth syndrome) oraz choroby tkanek przyzębia. Zapalenie dziąseł i przyzębia jest częstym powikłaniem, w niektórych przypadkach pojawiającym się już we wczesnym dzieciństwie. Częstość występowania i zaostrzeń widocznych $w$ postaci krwawienia z dziąseł wzrasta w okresie dojrzewania [6, 7]. Czas trwania choroby podstawowej i przede wszystkim wyrównanie metaboliczne w znaczący sposób wpływają na stan tkanek przyzębia [8]. $Z$ drugiej strony uważa się, że stan zapalny, charakterystyczny dla gingivitis i periodontitis, może przyczynić się do nasilenia insulinooporności, zaburzając wyrównanie metaboliczne cukrzycy. Cukrzyca nie jest zatem przyczyną, a raczej czynnikiem predysponującym do wystąpienia chorób dziąseł i przyzębia [6, 7]. Zaburzenie równowagi w metabolizmie glukozy obniża odporność na infekcje, a co za tym idzie ułatwia zapoczątkowanie, rozwój i zwiększa ryzyko powikłań gingivitis i periodontitis. $U$ pacjentów $z$ wyższym odsetkiem HbA1c zmniejsza się przepływ śliny, wzrasta odsetek krwawiących miejsc w dziąsłach, a także liczba ubytków próchnicowych.

Badania dowodzą, że istnieje wyraźny związek między stopniem wyrównania metabolicznego, wyrażonego w ocenie wskaźnika HbA1c, a zdrowiem jamy ustnej dzieci i dorosłych z cukrzycą typu 1 [9]. Przy podobnym stanie higieny jamy ustnej, pacjenci ze słabym wyrównaniem cukrzycy typu 1 
prezentowali większe nasilenie objawów zapalenia dziąseł niż pacjenci o wyrównaniu co najmniej dobrym do bardzo dobrego [10, 11].

\section{Cel}

Celem badania było porównanie stanu płytki nazębnej u dorosłych chorych na cukrzycę typu 1 leczonych metodą intensywnej insulinoterapii przy użyciu wstrzykiwaczy lub osobistej pompy insulinowej.

\section{Materiał i metody}

Po uzyskaniu zgody Komisji Bioetycznej do badania włączono 402 osoby (171 mężczyzn) z cukrzycą typu 1 w wieku 18-45 lat, z medianą trwania cukrzycy 12,5 roku. Wszyscy badani wyrazili świadomą zgodę na udział w badaniu. Kryteria wykluczające stanowiły: aktualne leczenie ortodontyczne, ciąża. U wszystkich pacjentów dokonano pomiarów antropometrycznych, obliczono wskaźnik masy ciała BMI (z wykorzystaniem wzoru: masa ciała $[\mathrm{kg}] /$ wzrost $\left.[\mathrm{m}]^{2}\right)$, oznaczono na czczo odsetek hemoglobiny glikowanej (HbA1C), cholesterol całkowity (T-Chol), białko C-reaktywne o wysokiej czułości (hs-CRP) z wykorzystaniem standardowych metod laboratoryjnych. U wszystkich pacjentów zastosowano do oceny stanu higieny i płytki nazębnej zmodyfikowany aproksymalny wskaźnik płytki (API) [12]. Badanie przeprowadziło dwóch skalibrowanych lekarzy stomatologów. W kwadrantach 1 i 3 badanie przeprowadzono od strony jamy ustnej, a w kwadrantach 2 i 4 od strony przedsionka. Jest to wskaźnik prosty do zastosowania w warunkach poradni, oceniający obecność płytki na powierzchniach stycznych, gdzie tworzy się ona szczególnie szybko i skąd nie jest łatwa do usunięcia. Ocena dokonywana jest w systemie zero-jedynkowym. Zmiana ilości złogów wyrażona w procentach stanowi podstawę oceny efektywności prowadzonych zabiegów higienizacyjnych. Poszczególne zakresy wskaźnika zinterpretowano zgodnie z podziałem: API < 25\% - higiena optymalna; API = 39-25\% - higiena prawie dobra; API $=70-40 \%$ - higiena przeciętna, do poprawy; API = 100-70\% - higiena niewłaściwa.

W zależności od sposobu podawania insuliny wydzielono: grupę MDI (ang. multiple daily injections, leczenie wielokrotnymi wstrzyknięciami insuliny z użyciem wstrzykiwaczy) oraz grupę OPI (leczenie ciągłym podskórnym wlewem insuliny za pomocą osobistej pompy insulinowej, OPI). Pacjenci w grupie OPI byli leczeni pompą osobistą od przynajmniej roku.

Wyniki poddano analizie statystycznej za pomocą programu Statistica PL wersja 10.0. Za istotny statystycznie przyjęto poziom istotności $p<0,05$. Ocenę zgodności rozkładu zmiennych z rozkładem normalnym wykonano za pomocą testu Kołmogorowa-Smirnowa z poprawką Lillieforsa. Do analizy danych użyto testów nieparametrycznych. W analizie statystycznej wykorzystano test U Manna-Whitneya oraz chi-kwadrat. Wyniki przedstawiono jako liczebności oraz mediany i rozstępy międzykwartylowe (IQR). Przeprowadzono analizę regresji wieloczynnikowej w celu oceny zmiennych niezależnie związanych z API.

\section{Wyniki}

191 (47\%) osób było leczonych ciągłym podskórnym wlewem insuliny za pomocą osobistej pom-

Tabela I. Charakterystyka grupy badanej. Porównanie grupy w zależności od metody insulinoterapii. $\mathrm{N}=402$. Mediana (rozstęp międzykwartylowy, IQR) lub liczba (n, \%). Test U Manna-Whitneya. *test $X^{2}$

Table 1. Characteristics of the study group. Evaluation of differences in subgroups according to the method of insulin therapy. $N=402$. Median (IQR) or number ( $n, \%)$. Mann-Whitney U-test; * Chi-square test

\begin{tabular}{|l|c|c|c|c|}
\hline & Cała grupa, $\mathrm{n}=402$ & MDI, $\mathrm{n}=191$ & OPI, $\mathrm{n}=211$ & $\mathrm{p}$ \\
\hline Wiek [lata] & $28(21,5-35)$ & $32(25-38)$ & $24(19-31)$ & $<0,0001$ \\
\hline Płeć [mężczyźni, $\mathrm{n}(\%)]$ & $171(42)$ & $97(46)$ & $73(38)$ & $0,1^{*}$ \\
\hline Czas trwania cukrzycy [lata] & $12,5(8-18)$ & $12(6-19)$ & $13(8-18)$ & 0,2 \\
\hline Palenie papierosów [(tak, $\mathrm{n}(\%)]$ & $91(22)$ & $64(30)$ & $27(14)$ & $0,0001^{*}$ \\
\hline HbA1c [\%] & $7,8(7-9)$ & $8,1(7,2-9,4)$ & $7,6(6,9-8,8)$ & 0,0004 \\
\hline BMI [kg/m2] & $23,45(21,6-26)$ & $24,4(22-27)$ & $22,9(21-24,8)$ & 0,00001 \\
\hline hs-CRP [mg/dl] & $0,9(0,44-2,12)$ & $1,15(0,61-2,68)$ & $0,63(0,33-1,5)$ & 0,000001 \\
\hline T-Chol [mg/dl] & $178(157-202)$ & $186(165-212)$ & $168,5(151-195)$ & 0,00007 \\
\hline API & $0,39(0,24-0,62)$ & $0,48(0,3-0,65)$ & $0,32(0,18-0,55)$ & 0,000001 \\
\hline
\end{tabular}

HbA1c — hemoglobina glikowana; BMI (body mass index) — wskaźnik masy ciała; T-Chol — cholesterol całkowity; hs-CRP (high sensitivity C-Reactive Protein) — białko C-reaktywne o wysokiej czułości; API (approximal plaque index) — aproksymalny wskaźnik płytki 
py insulinowej (OPI). Grupa ta charakteryzowała się młodszym wiekiem [24(19-31) lat vs $32(25-38)$ lat; $\mathrm{p}<0,0001]$, niższym wskaźnikiem masy ciała BMI $\left[22,9(21-24,8) \mathrm{kg} / \mathrm{m}^{2}\right.$ vs $24,4(22-27) \mathrm{kg} / \mathrm{m}^{2}$; $p=0,00001]$, lepszym wyrównaniem metabolicznym cukrzycy (wyrażonym niższym odsetkiem HbA1c $[7,6(6,9-8,8) \%$ vs $8,1(7,2-9,4) \% ; p=0,0004]$ oraz niższym stężeniem cholesterolu całkowitego $[168,5(151-195) \mathrm{mg} / \mathrm{dl}$ vs $186(165-212) \mathrm{mg} / \mathrm{dl}$; $\mathrm{p}=0,00007]$, mniejszym nasileniem stanu zapalnego (niższym stężeniem hs-CRP $[0,63(0,3-1,5)$ $\mathrm{mg} / \mathrm{dl}$ vs $1,15(0,61-2,68) \mathrm{mg} / \mathrm{dl} ; \mathrm{p}=0,000001])$ oraz niższym API $[0,32(0,18-0,55)$ vs $0,48(0,3-0,65)$; $p=0,000001]$ w porównaniu z grupą leczoną metodą wielokrotnych wstrzyknięć insuliny. Nie wykazano różnic w zakresie płci oraz czasu trwania cukrzycy pomiędzy obiema podgrupami. W grupie MDI wykazano większą częstość palenia papierosów $(p=0,0001)$. W całej badanej grupie wykazano dodatnią korelację API z wiekiem, HbA1c, T-Chol, hs-CRP, BMI. Płeć żeńska oraz leczenie OPI korelowało ujemnie z API. W analizie regresji wie-

Tabela 2. Korelacja API i wybranych parametrów laboratoryjnych, antropometrycznych oraz metody insulinoterapii. Współczynnik korelacji rang Spearmana, Rs

Table 2. Correlations between API, anthropometric data, laboratory parameters and the method of insulin therapy. Spearman rank correlation, $R s$

\begin{tabular}{|l|c|c|}
\hline & Rs & $p$ \\
\hline Wiek & 0,15 & 0,02 \\
\hline Płeć żeńska & $-0,1$ & 0,03 \\
\hline Palenie papierosów & 0,05 & 0,3 \\
\hline Leczenie OPI & $-0,24$ & 0,000001 \\
\hline BMI & 0,15 & 0,002 \\
\hline HbA1c & 0,17 & 0,0004 \\
\hline Hs-CRP & 0,1 & 0,03 \\
\hline T-Chol & 0,1 & 0,004 \\
\hline
\end{tabular}

Tabela 3. Analiza regresji wieloczynnikowej dla API. $\mathrm{R}^{2}=0,12, \mathrm{p}<0,0001$

Table 3. Multivariable regression analysis, $R^{2}=0.12$; $p<0.0001$

\begin{tabular}{|l|c|c|}
\hline & $\beta$ & $p$ \\
\hline Wiek & 0,08 & 0,2 \\
\hline Płeć żeńska & $-0,09$ & 0,07 \\
\hline Palenie papierosów & $-0,03$ & 0,5 \\
\hline Leczenie OPI & $-0,14$ & 0,01 \\
\hline BMI & 0,08 & 0,2 \\
\hline HbA1c & 0,15 & 0,004 \\
\hline hs-CRP & 0,08 & 0,1 \\
\hline T-Chol & 0,05 & 0,3 \\
\hline
\end{tabular}

loczynnikowej HbA1c oraz leczenie OPI były związane z API niezależnie od wieku, płci, palenia papierosów, oraz pozostałych parametrów ujętych w modelu (Tabela 3).

\section{Dyskusja}

Wyniki badań związanych z wyrównaniem metabolicznym w cukrzycy w odniesieniu do chorób przyzębia są niekiedy bardzo rozbieżne. Trudność w ich porównaniu wynika często z niewielkiej liczebności badanych grup, różnych wskaźników poddawanych ocenie i braku jednoznacznego określenia wspótistniejącej choroby przyzębia. W prezentowanym badaniu, w grupie 402 osób z cukrzycą typu 1 oceniono obecność płytki nazębnej za pomocą aproksymalnego wskaźnika płytki nazębnej. W badanej grupie nie stwierdzono przypadku obecności kieszonek przyzębnych, co pozwala zakwalifikować proces zapalny widoczny $w$ tkankach jako zapalenie dziąseł.

W przypadku zapalenia przyzębia przewlekła gram-ujemna infekcja $w$ tkankach jamy ustnej zwiększa insulinooporność, przyczyniając się do pogorszenia wyrównania metabolicznego cukrzycy [13]. Jednocześnie reakcja bakteryjnych produktów ubocznych z fagocytami i fibroblastami indukuje chroniczny wyrzut cytokin prozapalnych, m.in. interleukin: IL-1 $\beta$, IL-6, czynnik martwicy guza (TNF-a), prostaglandyny E2 (PGE2) oraz białka ostrej fazy C-reaktywnego (CRP) [14]. W prezentowanym badaniu także istniała statystycznie istotna zależność pomiędzy ilością płytki nazębnej a stężeniem białka CRP. Badania wskazują, że leczenie periodontologiczne może znacząco obniżyć stężenie CRP we krwi [15]. Znana jest również zależność między poziomem HbA1c a CRP. W przypadku niewyrównanej metabolicznie cukrzycy wyższe stężenia CRP są markerem przewlekłego stanu zapalnego o małym nasileniu (ang. low grade inflammation) [16]. Wykazaliśmy, że grupa gorzej wyrównana metabolicznie (wyższy odsetek HbA1c), leczona MDI, charakteryzowała się wyższym stężeniem hs-CRP i jednocześnie większą ilością płytki nazębnej. Wyniki są zgodne z obserwacjami grupy dzieci z cukrzycą typu 1, wskazującymi na większą akumulację płytki i większe nasilenie zapalenia dziąseł u dzieci z cukrzycą w porównaniu z dziećmi zdrowymi [6].

Meenawat i wsp. wykazali większe nasilenie stanu zapalnego, czego klinicznym objawem było wzmożone krwawienie z dziąseł u osób z cukrzycą typu 1 w porównaniu z grupą kontrolną. Wykazano również wyraźny związek między HbA1c a wskaźnikami PPD (Probing Pocket Depth), BI (Bleeding 
Index), CAL (Clinical attachment level), przy czym im gorsze było wyrównanie metaboliczne cukrzycy, tym wyższe wartości poszczególnych wskaźników, bez istotnych różnic w zakresie stanu higieny jamy ustnej oraz płytki nazębnej [17].

Badania na myszach z użyciem izotiocyjanku fluoresceiny i rodaminy wykazały, że obraz małych naczyń krwionośnych w warunkach hiperglikemii jest porównywalny do ostrego stanu zapalnego, ze zwiększoną przepuszczalnością śródbłonka, adhezją leukocytów i ich zwiększoną migracją. W związku z tym spostrzeżeniem, można wysunąć przypuszczenie, że sama hiperglikemia, w środowisku wolnym od innych potencjalnych czynników prozapalnych jest czynnikiem inicjującym stan zapalny, w ten sposób wyjaśniając rolę cukrzycy w rozwoju chorób przyzębia $[18,19]$. Badania Sima i wsp. potwierdzają wpływ podwyższonych przewlekle stężeń glukozy na marginalizację leukocytów i wynaczynianie makrocząsteczek w mikronaczyniach dziąseł, klinicznie dając objawy gingivitis [20]. U chorych na cukrzycę typu 1 wykazano aktywację krążących neutrofili. Następstwem tego zjawiska jest czopowanie naczyń mikrokrążenia oraz uwalnianie nadmiernej ilości reaktywnych form tlenu [21].

Badania na grupie 30 pacjentów z cukrzycą typu 1 w wieku 15-35 lat, z dobrze wyrównaną glikemią i 30 pacjentów w grupie kontrolnej, w podobnym wieku i rozkładzie płci wykazały znacznie większą akumulację płytki u osób zdrowych przy jednoczesnym znacznie mniejszym nasileniu stopnia zaawansowania chorób dziąseł i przyzębia. Na podstawie tej obserwacji autorzy przypuszczają, że możliwym czynnikiem sprawczym pozostaje miejscowe lub nawet systemowe upośledzenie odpowiedzi immunologicznej w sytuacji bakteriemii w jamie ustnej [22].

W naszym badaniu stwierdziliśmy mniejszą akumulację płytki u kobiet co jest zgodne $z$ tendencją do niższej higieny wśród mężczyzn bez cukrzycy [23].

Co ciekawe w badaniach na populacji dzieci okazało się, że więcej dziewczynek ma gorzej wyrównaną cukrzycę $(8 \%<\mathrm{HbA} 1 \leq 10 \%$ oraz HbA1c > $10 \%)$ niżej chłopców (HbA1c $\leq 8 \%)$ [9].

Wyniki naszych badań potwierdzają brak wpływu wieku na akumulację płytki, jednak istnieją doniesienia, w których oceniono, że do ok. 56 roku życia wskaźnik PI (wskaźnik kontroli płytki) był podobny w grupie osób z cukrzycą i kontrolnej i znacząco różny powyżej tej granicy [24, 25].

Nie wykazano związku między poziomem higieny i ilością kamienia nazębnego a stopniem wyrównania cukrzycy, natomiast okazało się, że przy podobnym poziomie higieny pacjenci w grupie o gorszym wyrównaniu metabolicznym (HbA1c $\geq 9,0 \%$ ) nasilenie objawów, opisanych wskaźnikami dziąsłowymi, płytki i kamienia nazębnego były istotnie większe [9].

Cetinkalp i wsp. w badaniach na 25 pacjentach z cukrzycą typu 1 (13 leczonych za pomocą osobistej pompy insulinowej i 12 metodą wielokrotnych wstrzyknięć insuliny) i 12 osobach w grupie kontrolnej nie stwierdzili różnicy w stężeniach markerów ryzyka sercowo-naczyniowego i miażdżycy: CRP, homocysteiny, fibrynogenu, oksydowanych lipoprotein o małej gęstości (oxLDL), inhibitora aktywatora plazminogenu (PAI-1), białka chemotaktycznego dla monocytów (MCP-1) i naczyniowo-śródbłonkowego czynnika wzrostu (VEGF). Jednakże osoby leczone za pomocą OPI charakteryzowały się wyższym odsetkiem HbA1c i wyższym stężeniem HDL-cholesterolu niż osoby w grupie MDI. Uzyskane wyniki sugerują, że zastosowanie obu metod intensywnej kontroli poziomu cukru chroni przed rozwojem powikłań makronaczyniowych [26].

Podsumowując należy podkreślić, że oba sposoby insulinoterapii, tj. MDI i OPI pozwalają osiągnąć ścisłą kontrolę glikemii, pod warunkiem przestrzegania przez pacjenta zasad intensywnej czynnościowej insulinoterapii, prowadzenia stałej edukacji diabetologicznej. U wysoce zmotywowanych osób wykorzystanie OPI pozwala uzyskać szczególną poprawę wyrównania metabolicznego cukrzycy [27] i obserwować pozytywne konsekwencje zmniejszenia stanu zapalnego, wyrażone laboratoryjnie niższym stężeniem CRP i klinicznie m.in. mniejszym nasileniem płytki nazębnej. W badanej grupie analiza regresji wieloczynnikowej wykazała, że leczenie OPI oraz lepsze wyrównanie metaboliczne cukrzycy (niższy odsetek HbA1c) były niezależnie związane z mniejszą akumulacją płytki nazębnej.

\section{Oświadczenia}

Oświadczenie dotyczące konfliktu interesów

Autorzy deklarują brak konfliktu interesów w autorstwie oraz publikacji pracy.

\section{Źródła finansowania}

Autorzy deklarują brak źródeł finansowania.

\section{Piśmiennictwo}

[1] American Diabetes A. 6. Glycemic Targets: Standards of Medical Care in Diabetes-2018. Diabetes Care. 2018;41(Suppl 1):S55-S64.

[2] Albers JW, Herman WH, Pop-Busui R, Feldman EL, Martin CL, Cleary PA, Waberski BH, Lachin JM, Dia- 
betes C, I. Complications Trial /Epidemiology of Diabetes, and G. Complications Research, Effect of prior intensive insulin treatment during the Diabetes Control and Complications Trial (DCCT) on peripheral neuropathy in type 1 diabetes during the Epidemiology of Diabetes Interventions and Complications (EDIC) Study. Diabetes Care. 2010;33(5):1090-6.

[3] Stratton IM, Adler Al, Neil HA, Matthews DR, Manley SE, Cull CA, Hadden D, Turner RC, Holman RR. Association of glycaemia with macrovascular and microvascular complications of type 2 diabetes (UKPDS 35): prospective observational study. BMJ. 2000;321(7258):405-12.

[4] Zalecenia kliniczne dotyczące postępowania u chorych na cukrzycę. 2018. Stanowisko Polskiego Towarzystwa Diabetologicznego. Diabetologia Kliniczna. 2018;4(1).

[5] Karges B, Schwandt A, Heidtmann B, Kordonouri O, Binder E, Schierloh U, Boettcher C, Kapellen T, Rosenbauer J, Holl RW. Association of Insulin Pump Therapy vs Insulin Injection Therapy With Severe Hypoglycemia, Ketoacidosis, and Glycemic Control Among Children, Adolescents, and Young Adults With Type 1 Diabetes. JAMA. 2017;318(14):1358-1366.

[6] Lalla E, Cheng B, Lal S, Tucker S, Greenberg E, Goland $\mathrm{R}$, Lamster IB. Periodontal changes in children and adolescents with diabetes: a case-control study. Diabetes Care. 2006;29(2):295-9.

[7] Xavier AC, Silva IN, Costa Fde O, Correa DS. [Periodontal status in children and adolescents with type 1 diabetes mellitus]. Arq Bras Endocrinol Metabol. 2009;53(3):348-54.

[8] Luczaj-Cepowicz E, Marczuk-Kolada G, Waszkiel D. Evaluation of periodontal status in young patients with insulin-dependent diabetes mellitus (type 1). Adv Med Sci. 2006;51(Suppl. 1):134-7.

[9] Carneiro VL, Fraiz FC, Ferreira Fde M, Pintarelli TP, Oliveira AC, Boguszewski MC. The influence of glycemic control on the oral health of children and adolescents with diabetes mellitus type 1. Arch Endocrinol Metab. 2015;59(6):535-40.

[10] Sollecito TP, Sullivan KE, Pinto A, Stewart J, Korostoff J. Systemic conditions associated with periodontitis in childhood and adolescence. A review of diagnostic possibilities. Med Oral Patol Oral Cir Bucal. 2005;10(2):142-50.

[11] Orbak R, Simsek S, Orbak Z, Kavrut F, Colak M. The influence of type-1 diabetes mellitus on dentition and oral health in children and adolescents. Yonsei Med J. 2008;49(3):357-65.

[12] Lange DE, Plagmann HC, Eenboom A, Promesberger A. [Clinical methods for the objective evaluation of oral hygiene]. Dtsch Zahnarztl Z. 1977;32(1):44-7.

[13] Llambes F, Silvestre FJ, Hernandez-Mijares A, Guiha $R$, Caffesse R. The effect of periodontal treatment on metabolic control of type 1 diabetes mellitus. Clin Oral Investig. 2008;12(4):337-43.

[14] D'Aiuto F, Parkar M, Andreou G, Suvan J, Brett PM, Ready D, and MS Tonetti, Periodontitis and systemic inflammation: control of the local infection is associated with a reduction in serum inflammatory markers. J Dent Res. 2004;83(2):156-60.
[15] Nelson RG. Periodontal disease and diabetes. Oral Dis. 2008;14(3):204-5.

[16] Heier M, Margeirsdottir HD, Brunborg C, Hanssen $\mathrm{KF}$, Dahl-Jorgensen K, Seljeflot I. Inflammation in childhood type 1 diabetes; influence of glycemic control. Atherosclerosis. 2015;238(1):33-7.

[17] Meenawat A, Punn K, Srivastava V, Meenawat AS, Dolas RS, Govila V. Periodontal disease and type I diabetes mellitus: Associations with glycemic control and complications. J Indian Soc Periodontol. 2013;17(5):597-600.

[18] Pober JS, Sessa WC. Evolving functions of endothelial cells in inflammation. Nat Rev Immunol. 2007;7(10):803-15.

[19] Hickey MJ, Kubes P. Intravascular immunity: the host-pathogen encounter in blood vessels. Nat Rev Immunol. 2009;9(5):364-75.

[20] Sima C, Rhourida K, Van Dyke TE, Gyurko R. Type 1 diabetes predisposes to enhanced gingival leukocyte margination and macromolecule extravasation in vivo. J Periodontal Res. 2010;45(6):748-56.

[21] Zozulinska DA, Wierusz-Wysocka B, Wysocki H, Majchrzak $A E$, Wykretowicz $A$. The influence of insulin-dependent diabetes mellitus (IDDM) duration on superoxide anion and hydrogen peroxide production by polymorphonuclear neutrophils. Diabetes Res Clin Pract. 1996;33(3):139-44.

[22] Miralles-Jorda L, Silvestre-Donat FJ, Grau Garcia-Moreno DM, Hernandez-Mijares A. Buccodental pathology in patients with insulin-dependent diabetes mellitus: a clinical study. Med Oral. 2002;7(4):298302.

[23] RG. Choroby przyzębia. 2002, Warszawa: Dział Wydawnictw Akademii Medycznej.

[24] lughetti L, Marino R, Bertolani MF, Bernasconi S. Oral health in children and adolescents with IDDM--a review. J Pediatr Endocrinol Metab. 1999;12(5 Suppl. 2):603-10.

[25] Harrison R, Bowen WH. Periodontal health, dental caries, and metabolic control in insulin-dependent diabetic children and adolescents. Pediatr Dent. 1987;9(4):283-6.

[26] Cetinkalp S, Felekoglu C, Karadeniz M, Boyacioglu $H$, Delen Y, Yildirim E, Yilmaz C. Comparison of the effects of intensive insulin treatment modalities on cardiovascular biomarkers in type 1 diabetes mellitus. Diabetes Metab Syndr. 2015;9(3):157-62.

[27] Pickup JC. Is insulin pump therapy effective in Type 1 diabetes? Diabet Med. 2018.

Zaakceptowano do edycji: 2018-10-16 Zaakceptowano do publikacji: 2018-12-05

Adres do korespondencji:

Mateusz Tarnowski

tel.: +48602441 116

e-mail: m.tarnowski1992@gmail.com 